\title{
Zbigniew CZACHÓR
}

Poznań

\section{Europejska Strategia Bezpieczeństwa 2003-2008. Analiza politologiczna}

\section{Podstawy polityczne i traktatowe Europejskiej Strategii Bezpieczeństwa. Konsekwencje braku ratyfikacji Traktatu ustanawiającego Konstytucję dla Europy i Traktatu z Lizbony}

$\mathbf{W}$ Traktacie o Unii Europejskiej z Maastricht przyjęto, iż Wspólna Polityka Zagraniczna i Bezpieczeństwa obejmie kwestie związane z bezpieczeństwem Unii Europejskiej (UE), włącznie z ewentualnym określeniem wspólnej polityki obronnej, która z czasem, poprzez ewolucyjne zmiany doprowadzić może do wspólnej obronności. Unia Zachodnioeuropejska (UZE) w traktacie tym uznana została za integralną część rozwoju Unii, mającą za zadanie określanie i realizację decyzji i działań UE, mających skutki dla obronności. Potwierdzają to dwie deklaracje dołączone do Aktu Końcowego IGC $^{1}$, która te zmiany przygotowała i zatwierdziła. Pierwszą z nich była deklaracja w sprawie roli UZE i jej stosunków z UE i NATO. Państwa członkowskie wsparły w niej potrzebę ustanowienia autentycznej tożsamości bezpieczeństwa i obrony oraz większej odpowiedzialności europejskiej w kwestiach obronnych. Założono, że tożsamość ta będzie tworzona stopniowo, w wieloetapowym procesie. Deklaracja poza charakterystyką relacji z UE i Paktem Północnoatlantyckim zawierała też odniesienia do zadań operacyjnych UZE. Druga deklaracja przyjęta została przez państwa członkowskie UZE. Podkreślono tam wagę Europejskiej Tożsamości w zakresie Bezpieczeństwa i Obrony (ESDI) oraz UZE jako istotnego elementu obronnego UE oraz środka wzmacniającego europejski filar Sojuszu Atlantyckiego.

Traktat Amsterdamski nie przyniósł oczekiwanego przełomu w stosunkach pomiędzy UE a Unią Zachodnioeuropejską. WPZiB obejmować miała wszystkie kwestie związane z bezpieczeństwem Unii, włącznie z docelowym sformułowaniem wspólnej polityki obronnej, która w myśl Traktatu z Maastricht mogłaby prowadzić do wspólnej obrony, o ile decyzję taką uwzględniającą porządek konstytucyjny krajów członkowskich podjęłaby Rada Europejska. W następstwie tego UE, a konkretnie Rada Europejska uprawniona została do ustanowienia ściślejszych stosunków instytucjonalnych z UZE w celu ewentualnego włączenia UZE do UE.

W kompetencje UE włączono tzw. Zadania (Misje) Petersberskie ${ }^{2}$, czyli misje humanitarne i ratunkowe, operacje utrzymywania i przywracania pokoju oraz tzw. crisis management.

Kwestie obronne uregulowane zostały też w amsterdamskich protokołach i deklaracjach. Protokół dołączony do $\mathrm{TUE}^{3}$ zdecydowanie podkreślał, iż postanowienia traktatowe nie

\footnotetext{
${ }^{1}$ IGC - konferencja międzyrządowa.

${ }^{2}$ Tzw. misje peace-keeping.

${ }^{3}$ TUE - Traktat o Unii Europejskiej.
} 
mogą naruszać specyficznego charakteru polityki bezpieczeństwa i obronnej niektórych państw członkowskich, respektując ich zobowiązania realizowane w ramach NATO. W zbiorze protokołów dołączonych do TUE i TWE ${ }^{4}$ znalazł się również protokół dotyczący Danii. Uznano tam, prawo Danii do nieuczestniczenia w opracowywaniu i wykonywaniu decyzji i działań Unii, które mają skutki dla obronności. Warto też zwrócić uwagę na załączoną do Traktatu Amsterdamskiego deklarację, przyjętą przez Radę Ministrów Unii Zachodnioeuropejskiej w dniu 22 lipca 1997 roku. Dotyczyła ona relacji UZE z UE i NATO.

Jeszcze przed wejściem w życie Traktatu Amsterdamskiego, państwa członkowskie rozpoczęły pogłębioną debatę na temat przyszłości komponentu obronnego w ramach WPZiB. W dyskusjach tych najdonioślejsze znaczenie miała zmiana stanowiska Wielkiej Brytanii, co widoczne już było na nieformalnym spotkaniu szefów państw i rządów w Pörtschach w październiku 1998 r. Brytyjski premier T. Blair, krytykując ówczesną sytuację, w związku ze słabością i niejasnością funkcjonowania WPZiB co do wydarzeń w Bośni i Kosowie, po raz pierwszy nie wykluczył możliwej inkorporacji Unii Zachodnioeuropejskiej do UE, a co więcej, nawoływał do stworzenia nowoczesnych sił europejskich, dla pełnego urzeczywistnienia celów zawartych w ESDI ${ }^{5}$.

Poważnym pretekstem do zmian, które następowały w tym zakresie stał się termin wygaśnięcia mocy obowiązującej Traktatu Brukselskiego, na podstawie którego utworzono UZE. Data upłynięcia jego ważności okazała się jednak przedmiotem sporu. Zgromadzenie UZE stanęło na stanowisku, że datą tą będzie rok 2004, opierając się na zmodyfikowanym traktacie (Paryż, 1954 r.). Państwa członkowskie uznały natomiast, iż okres 50 lat ważności traktatu upłynął w 1998 r. ${ }^{6}$, ale z racji, że nie został on wypowiedziany, obowiązuje nadal ${ }^{7}$.

4 grudnia 1998 r. Wielka Brytania i Francja przyjęły wspólną deklarację o obronie europejskiej w traktacie spotkania na szczycie w Saint-Malo. Oba państwa uzgodniły, że Unia Europejska powinna odgrywać większą rolę na arenie międzynarodowej, bazując na zapisach Traktatu Amsterdamskiego. W deklaracji uznano, że Unia w razie kryzysów powinna być zdolna do przeprowadzenia autonomicznych działań z użyciem sił zbrojnych, jakkolwiek bez naruszania zobowiązań niektórych państw członkowskich należących do NATO i UZE. Nie przesądzając o przyszłości Unii Zachodnioeuropejskiej, stwierdzono, że UE powinna posiadać odpowiednie struktury i zdolności analizowania sytuacji kryzysowych, zdobywania materiałów szpiegowskich i możliwości planowania strategicznego bez powielania stanu posiadania $\mathrm{UZE}^{8}$.

Szczyt francusko-brytyjski w Saint-Malo, a następnie szczyt Rady Europejskiej w Kolonii, w czerwcu 1999 roku, stały się politycznym impulsem ustanawiającym generalne wytyczne wymagane dla rozwoju nowego systemu współpracy i koordynacji nazwanego Wspólną Europejską Polityką w zakresie Bezpieczeństwa i Obrony (WEPBiO). Na szczycie Rady Europejskiej w Kolonii (3 i 4 czerwca 1999 r.), przyjęta została deklaracja dotycząca rozwoju WEPBiO. Zgodnie z treścią deklaracji uznano, iż celem WEPBiO jest zapobieganie konfliktom oraz rozwiązywanie kryzysów przy wykorzystaniu formuły Misji Petersberskich, bez

\footnotetext{
${ }^{4}$ TWE - Traktat o Wspólnocie Europejskiej.

${ }^{5}$ A. Podraza, Wspólna Polityka Zagraniczna i Bezpieczeństwa: Unia Europejska potęga militarna??, w: Traktat Nicejski, red. A. Podraza, Lublin 2001, s. 150.

${ }^{6}$ Pierwsza wersja Traktatu Brukselskiego przyjęta została w 1948 r.

${ }^{7}$ R. Zięba, Instytucjonalizacja bezpieczeństwa europejskiego. Koncepcje-struktury - funkcjonowanie, Warszawa 2001, s. 195.

${ }^{8}$ A. Podraza, op. cit., s. 151-152.
} 
uszczerbku dla działań NATO i w zgodzie z zasadami Karty Narodów Zjednoczonych. Rada Europejska w Kolonii przyjęła, iż realizacja tych zadań wymagać będzie: - osiągnięcia przez UE niezbędnych zdolności i narzędzi działania; - ustanowienia ścisłej współpracy z Paktem Północnoatlantyckim; - stworzenia przemysłowej i technologicznej bazy wspólnej obrony; - włączenia UZE do UE (w niezbędnym zakresie) do końca 2000 r. ${ }^{9}$

W kilka miesięcy po „szczycie” państw członkowskich UE w Kolonii 25 listopada 1999 r. J. Solana został Sekretarzem Generalnym UZE, nie rezygnując z funkcji Wysokiego Przedstawiciela Unii Europejskiej do spraw WPZiB.

Na szczycie Rady Europejskiej w Helsinkach (10 i 11 grudnia 1999 r.), Rada Europejska potwierdziła swój zamiar przyznania Unii Europejskiej autonomicznej zdolności do podejmowania decyzji w sprawach obronnych. Szefowie państw lub rządów państw członkowskich UE postanowili, że w przypadku ew. kryzysów międzynarodowych Unia Europejska podejmie się rozpoczęcia i przeprowadzenia operacji wojskowych tylko wtedy, gdy NATO wykaże brak faktycznego nim zainteresowania (zaangażowania, uczestnictwa). Pomimo, iż w działaniach w sytuacjach kryzysowych na terytorium poza Unią naturalne pierwszeństwo dla UE ma obszar leżący relatywnie blisko jej granic, to żaden z traktatów, ani też konkluzje Rady Europejskiej nie wprowadzają żadnych ograniczeń geograficznych dla działań prowadzonych za jej zgodą. Podczas obrad Rady Europejskiej w Helsinkach, ustalony w Kolonii zamiar został urzeczywistniony poprzez przyjęcie konkretnych celów dotyczących utworzenia wiarygodnych, dostępnych i efektywnych sił europejskich (European Headline Goal). Zgodnie z nim (znanym jako „operacyjny cel helsiński”) państwa członkowskie zobowiązały się, w ramach dobrowolnej współpracy, osiagnąć do roku 2003 zdolność do natychmiastowego wystawienia (w ciągu 60 dni) i utrzymania (przynajmniej przez rok) sił zbrojnych zdolnych do wykonania pełnego zakresu Misji Petersberskich, jak ustalono w Traktacie z Amsterdamu, także tych, które wymagają zaangażowania znacznych sił, nawet wielkości korpusu (do 15 brygad lub 50 000-60 000 żołnierzy). Państwa członkowskie zgodnie z postanowieniami helsińskimi powinny być także zdolne do rozwinięcia mniejszych jednostek szybkiego reagowania. Siły te powinny być samowystarczalne, posiadać niezbędne dowództwo, kontrolę i zdolność wywiadowcza, zaplecze logistyczne i inne służby wsparcia w walce, a ponadto, jeśli to wskazane, jednostki powietrzne i morskie.

W Helsinkach postanowiono także, że: - w ramach Rady UE powstaną, nie naruszając jednolitości instytucjonalnej, nowe polityczne i wojskowe organy oraz struktury, co umożliwi Unii sprawowanie koniecznego nadzoru politycznego i strategicznego kierowania takimi operacjami; - zostaną wypracowane sposoby wszechstronnego konsultowania, pełnej współpracy oraz osiagnięcia przejrzystości między UE a NATO, uwzględniające potrzeby wszystkich krajów członkowskich UE; - zostaną określone właściwe rozwiązania, które pozwolą, przy zachowaniu autonomii decyzyjnej UE, europejskim członkom NATO, państwom nie należącym do UE oraz innym zainteresowanym krajom na udział w zarządzaniu sytuacjami kryzysowymi; - przyjęty zostanie mechanizm cywilnego zarządzania sytuacjami kryzysowymi w celu koordynowania i zwiększenia efektywności różnych środków i zasobów cywilnych, jakimi dysponuje Unia i kraje członkowskie, równolegle do środków i zasobów wojskowych ${ }^{10}$.

\footnotetext{
${ }^{9}$ S. Parzymies, Wspólna Europejska Polityka Bezpieczeństwa i Obrony, „Stosunki Międzynarodowe” 2000, nr 1-2 (t. 21), s. 13-14.

${ }^{10}$ Wspólna Polityka Bezpieczeństwa i Obrony. Posiedzenie Rady Europejskiej w Helsinkach, 10 - 11 grudnia 1999 r., Wnioski Prezydencji, w: Spotkania Rady Europejskiej 1993-2002. Wybór dokumentów, t. I, Warszawa 2002, s. 305 .
} 
Na mocy postanowień Rady Europejskiej w Helsinkach 1 marca 2000 r. utworzono nowe stałe organy polityczne i wojskowe ${ }^{11}$. Pierwszym stał się Komitet do spraw Politycznych i Bezpieczeństwa (PSC - Political and Security Committee), z siedzibą w Brukseli. Komitet ten składa się z przedstawicieli państw członkowskich na szczeblu wysokich urzędników lub ambasadorów. Zajmuje się wszystkimi aspektami WPZiB, w tym (Wspólnej) Europejskiej Polityki w zakresie Bezpieczeństwa i Obrony, zgodnie z przepisami Traktatu o UE, bez uszczerbku dla kompetencji wspólnotowych. W przypadku operacji wojskowej procedura zarządzania sytuacją kryzysową prowadzona w Komitecie sprawowana będzie z upoważnienia Rady UE.

Komitet do spraw Politycznych i Bezpieczeństwa przekazywać będzie swe wytyczne Komitetowi Wojskowemu, składającemu się z wojskowych przedstawicieli szefów sztabów ${ }^{12}$. Komitet ten upoważniony został do przygotowywania Komitetowi do spraw Politycznych i Bezpieczeństwa rad i zaleceń o charakterze wojskowym, a wskazówek - Sztabowi Wojskowemu (The European Union Military Staff - EUMS). Przewodniczący Komitetu Wojskowego bierze udział w posiedzeniach Rady UE, gdy decyduje ona w sprawach obronnych. Sztab Wojskowy, w ramach struktur Rady UE (a ściśle Sekretariatu Generalnego) przygotowuje analizy w kwestiach wojskowych oraz wspiera realizację zadań w zakresie WEPBiO, łącznie z prowadzeniem wojskowych operacji w trakcie zarządzania sytuacjami kryzysowymi. Do zadań Sztabu Wojskowego należy też wczesne ostrzeganie, ocena sytuacji i planowanie strategiczne dla realizacji Misji Petersberskich. Sztab kierowany jest przez gen. lt. R. Schuwirtha ${ }^{13}$, sprawującego, zgodnie z unijną nomenklaturą administracyjną, funkcję Generalnego Dyrektora.

22 maja 2000 r. utworzony został Komitet do spraw Cywilnych Aspektów Zarządzania Kryzysami $^{14}$. W konsekwencji tej decyzji w trakcie posiedzenia Rady Europejskiej w Feira (w 2000 r.) państwa członkowskie podjęły decyzję, iż od roku 2003 będą w stanie wystawić 5000 oficerów policji w ramach misji międzynarodowych w zakresie zapobiegania i opanowywania sytuacji kryzysowych. Uznano tam, że jednostki policyjne mogłyby być rozmieszczone na prośbę ONZ, OBWE czy też wchodzić w skład operacji samej Unii Europejskiej w sile do 1000 oficerów policji rozmieszczonych w ciągu 30 dni. Wkład poszczególnych krajów do sił policyjnych został przesądzony 10 maja 2001 r., kiedy to poinformowano o utworzeniu w Sekretariacie Rady UE wydziału ds. policji, który stał się częścią systemu WEPBiO ${ }^{15}$.

22 listopada 2000 r. Rada UE opublikowała deklarację w sprawie zdolności militarnych UE. Potwierdzono w niej cele zapisane w czasie posiedzeń Rady Europejskiej w Kolonii, Helsinkach i Feira. Deklaracja zawierała precyzyjne zapisy dotyczące: - wspólnych sił zbrojnych (60 tys. żołnierzy, gotowych do działania w czasie krótszym niż 60 dni na okres minimum 1 roku); - rezerwy militarnej w wysokości ponad 100 tys. żołnierzy, ok. 400 samolotów bojowych i 100 okrętów; - włączenia w możliwe operacje sztabów narodowych i multinarodowych; - współpracy z NATO.

W wyniku przyjęcia Traktatu z Nicei z TUE usunięte zostały zapisy o UZE jako integralnej części rozwoju Unii Europejskiej oraz o roli UZE w określaniu aspektów obronnych UE oraz opracowywaniu i wykonywaniu decyzji i działań Unii mających implikacje w dziedzinie obrony ${ }^{16}$.

\footnotetext{
${ }^{11}$ Ibidem, s. 306.

${ }^{12} \mathrm{~W}$ razie konieczności Komitet ten może obradować na szczeblu szefów sztabu.

${ }^{13}$ Stan na początek roku 2004.

${ }^{14}$ R. Zięba, op. cit., s. 212-216.

${ }^{15}$ A. Podraza, op. cit., s. 169.

${ }^{16}$ Decyzje w sprawie przyszłości UZE mają zapaść w roku 2004.
} 
Traktat Nicejski wpisał Komitet do spraw Politycznych i Bezpieczeństwa wraz z jego kompetencjami do TUE. Powierzenie Komitetowi do spraw Politycznych i Bezpieczeństwa kontroli i strategicznego kierownictwa nad operacjami kryzysowymi było przyczynkiem do istotnej zmiany wewnętrznej w strukturze WPZiB i EPBiO ${ }^{17}$. Komitetowi przekazana została delegacja do podejmowania niezbędnych decyzji z upoważnienia Rady UE, szczególnie dotyczących kontroli politycznej i kierownictwa strategicznego operacji zarządzania kryzysami. Przyjęte rozwiązanie potwierdza w pełni włączenie zadań UZE w obszar kompetencyjny Unii Europejskiej i stopniowe „wygaszanie jej” zadań. Warto też podkreślić, iż reguły wzmocnionej współpracy wprowadzone do WPZiB Traktatem Nicejskim nie odnosiły się do spraw mających implikacje wojskowe lub w dziedzinie obrony.

Bardzo ważne treści dotyczące EPBiO znalazły się również w konkluzjach przyjętych na zakończenie obrad Rady Europejskiej w Nicei ${ }^{18}$. Dokonano tam podsumowania dotychczasowych działań oraz sprecyzowano plany na następne miesiące i lata. Wprowadzono tam zapowiedzi dalszych prac nad: - militarnymi i cywilnymi aspektami operacji w stanach kryzysu; - przygotowaniem operacyjnym sił zbrojnych UE; - międzynarodowym zaangażowaniem sił policyjnych; - dalszą rozbudową instytucjonalną $\mathrm{EPBiO}^{19}$; - współpracą z państwami trzecimi (w tym przystępującymi do UE), z NATO i ONZ, a także OBWE i Radą Europy; - utworzeniem Centrum Satelitarnego i Instytutu Badań nad Bezpieczeństwem.

Na szczycie Rady Europejskiej w Göteborgu (15 i 16 czerwca 2001 r.), szefowie państw i rządów państw członkowskich podjęli ważną decyzję o pogłębieniu współpracy między Unią Europejską a Narodami Zjednoczonymi, zwłaszcza w dziedzinie zapobiegania konfliktom i zarządzania w warunkach kryzysowych. Podczas obrad Rady Europejskiej w Laeken dyskutowano o planie wzmocnienia potencjału operacyjnego Unii Europejskiej (ECAP), którego ramy zostały określone w czasie konferencji konsultacyjnej w Brukseli, która odbyła się 19 listopada 2001 r. i dotyczyła doskonalenia możliwości sił zbrojnych i policji w zakresie zarządzania kryzysowego (Capabilities Improvement Conference) ${ }^{20}$.

W trakcie posiedzenia Rady Europejskiej w Sewilli (21-22 czerwca 2002 r.) zdecydowano się wzmocnić rolę UE w zwalczaniu terroryzmu. Wyrazem tego była deklaracja RE w sprawie nadania zdolności operacyjnej EPBiO w walce $z$ terroryzmem ${ }^{21}$. Tematyka ta w trakcie kolejnych prezydencji stała się stałym elementem prac gremiów i instytucji Unii Europejskiej.

Postanowienia zawarte w konkluzjach Rady Europejskiej w Nicei zostały przypomniane i rozwinięte w Załączniku nr II do konkluzji Rady Europejskiej w Brukseli z 24-25 października 2002 r. ${ }^{22}$ Jak uzgodniono w Nicei, Unia Europejska zobowiązana została do prowadzenia stałych konsultacji z sojusznikami europejskimi spoza tej organizacji, obejmującymi cały za-

${ }^{17}$ Traktat o Unii Europejskiej, Traktat ustanawiajacy Wspólnotę Europejska, w: Traktaty i komentarze, red. Z. Brodecki, M. Drobysz, S. Majkowska, Warszawa 2002, s. 73.

${ }^{18}$ Presidency Report on the European Security and Defence Policy, Annex VI, Nice European Council. Presidency Conclusions, Press Release: Brussels (8/12/2000) Nr: 400/1/00. W dokumentach tych nie używa się już nazwy i skrótu CESDP (WEPBiO) a ESDP (EPBiO).

${ }^{19}$ Anlage VIzu den Schlussfolgerungen des Vorsitzes des Europäischen Rates in Nizza vom 7., 8. und 9. Dezember. Bericht über die Europäische Sicherheits- und Verteidigungspolitik, „Internationale Politik” 2001, nr 5, s. 83-89.

${ }^{20}$ Posiedzenie Rady Europejskiej w Laeken, 14-15 grudnia 2001 r., Wnioski Prezydencji, w: Spotkania Rady..., op. cit., s. 157.

${ }^{21}$ Załacznik nr V. Projekt deklaracji Rady Europejskiej w Sewilli w sprawie wkładu WPZiB, włacznie z EPBiO, w walke z terroryzmem, w: Spotkania Rady..., op. cit., s. 237-239.

${ }^{22}$ Załacznik nr II do Wniosków Prezydencji, Posiedzenie Rady Europejskiej w Brukseli, 24-25 października 2002 r., „Monitor Integracji Europejskiej” 2002, nr 59, s. 97-100. 
kres zagadnień związanych z bezpieczeństwem, obroną i zarządzaniem kryzysowym. Konsultacje zewnętrzne prowadzone są $\mathrm{w}$ formule $\mathrm{UE}+6$ szczególnie przed posiedzeniami Komitetu do spraw Politycznych i Bezpieczeństwa i Komitetu Wojskowego UE. Konsultacje te przygotowują Prezydencja, Sekretariat Rady i przedstawiciele sojuszników. W myśl zapisów załącznika Unia Europejska nie zamierza prowadzić ćwiczeń wojskowych poniżej poziomu dowódczego. Odpowiedzialność za ćwiczenia poniżej tego szczebla spoczywać będzie na państwach członkowskich. Poza tym postanowiono, że podczas rozważania sposobu reakcji na zaistniały kryzys, w tym możliwości podjęcia operacji pod kierownictwem UE, Unia weźmie pod uwagę interesy i problemy europejskich sojuszników spoza UE. Jeżeli będzie to operacja prowadzona pod kierownictwem UE z wykorzystaniem zasobów i możliwości NATO, sojusznicy europejscy spoza UE, o ile sobie tego zażyczą, będą uczestniczyć w przygotowaniu takiej operacji zgodnie z procedurami obowiązującymi w NATO. W przypadku operacji prowadzonej pod kierownictwem UE, lecz bez korzystania z zasobów i możliwości NATO, sojusznicy europejscy spoza UE zostaną zaproszeni do uczestnictwa w niej na mocy decyzji Rady UE. W przypadku podjęcia przez Radę UE decyzji o rozpoczęciu operacji zbrojnej oraz po przeprowadzeniu konferencji o wydzieleniu sił do tej operacji zostanie ustanowiony i zwołany Komitet Uczestników w celu omówienia i sfinalizowania wstępnych planów operacyjnych i przygotowań wojskowych do operacji. Tak jak to przewidziano w Nicei, Komitet Uczestników odgrywać będzie zasadniczą rolę w codziennym zarządzaniu operacją. Komitet zajmie się też omówieniem raportów Dowódcy Operacji oraz będzie służyć pomocą Radzie do spraw Polityki i Bezpieczeństwa ${ }^{23}$.

Rok 2003 z punktu widzenia realizacji celów EPBiO był czasem zahamowania ewolucyjnej zmiany w obszarze wspólnej polityki obronnej, wywołanego przede wszystkim sporem w relacjach UE-NATO i w samej Unii Europejskiej w związku z interwencją zbrojną w Ira$\mathrm{ku}^{24}$. Doszło w tej sprawie do sporu zarówno wśród krajów członkowskich jak i kandydujących, a dowodem na to stał się „Wspólny dokument (list) premierów w sprawie Iraku” z 30 stycznia 2003 r. 17 lutego 2003 r. zwołana została także nadzwyczajna Rada Europejska poświęcona li tylko sytuacji w Iraku ${ }^{25}$. Nie zapobiegło to jednak interwencji zbrojnej w tym kraju i sporom wokół niej między członkami UE i NATO.

W konsekwencji 29 kwietnia 2003 r. Niemcy, Francja, Belgia i Luksemburg w trakcie szczytu w Brukseli zdecydowały o powołaniu Europejskiej Unii Bezpieczeństwa i Obrony (EUBiO), której członkowie na wzór art. 5 Traktatu Waszyngtońskiego (NATO) zobowiązują się do przyjścia sobie z pomocą w sytuacji zagrożenia. Uznano, że organizacja ta ma być otwarta dla wszystkich krajów należących do UE, prowadzić ma do harmonizacji stanowisk państw członkowskich w sprawach bezpieczeństwa i obrony, a także koordynować rozwój ich zdolności obronnych ${ }^{26}$. Jedną z inicjatyw EUBiO ma być powołanie europejskich sił szybkiego reagowania, których podstawą stanie się istniejąca już francusko-niemiecka brygada wzmocniona belgijskimi jednostkami komandosów i luksemburskimi wojskami zwiadowczymi $^{27}$. Dyskutowano też o powołaniu sztabu operacyjnego UE, który zająłby się planowa-

\footnotetext{
${ }^{23}$ Ibidem, s. 100 .

${ }^{24}$ Interwencja z głównym udziałem sił zbrojnych USA i W. Brytanii rozpoczęła się 20 marca $2003 \mathrm{r}$.

${ }^{25}$ Extraordinary European Council 17 February 2003 - Presidency conclusions, Council of the European Union, 6466/03, Brussels, 21 February 2003.

${ }^{26}$ Gemeinsame Erklärung Deutschlands, Frankreichs, Luxemburgs und Belgiens zur Europäischen Sicherheitsund Verteidigungspolitik, Brüssel, 29. April 2003. Tekst pobrano ze strony internetowej www.bundesregierung.de.

27 J. Bielecki, Nie jesteśmy puczystami, ,Rzeczpospolita” 2003, 30 kwietnia 2003, s. A6.
} 
niem i nadzorowaniem operacji autonomicznych UE, w których nie będą wykorzystywane zasoby i zdolności NATO. Nie bez znaczenia jest tu fakt, że kilka tygodni wcześniej 20-21 marca 2003 r. w trakcie obrad Rady Europejskiej w Brukseli zaproponowano utworzenie przez Radę UE międzyrządowej agencji do spraw rozwoju potencjału obronnego oraz zakupów sprzętu wojskowego ${ }^{28}$. Potwierdzili to ministrowie obrony w listopadzie 2003 r. podejmując decyzję o formalnym utworzeniu do czerwca 2004 r. Europejskiej Agencji Uzbrojenia, Badań i Potencjału Wojskowego. Europejską Agencję Obrony powołano na podstawie wspólnego działania Rady z dnia 12 lipca 2004 r. w celu poprawy zdolności obronnych UE, w szczególności w obszarze zarządzania kryzysowego; promowania europejskiej współpracy w dziedzinie uzbrojenia; wzmocnienia europejskiego przemysłu obronnego i bazy technologicznej oraz stworzenia konkurencyjnego europejskiego rynku uzbrojenia; wspierania badań w celu wzmocnienia przemysłowego i technologicznego potencjału w zakresie zdolności obronnych. Obecnie do zadań Agencji należy: wypracowanie spójnego i systematycznego podejścia przy definiowaniu i realizacji Europejskiej Polityki Bezpieczeństwa i Obrony; wspieranie współpracy między Państwami Członkowskimi w dziedzinie uzbrojenia; wspieranie rozwoju i ogólna restrukturyzacja europejskiego przemysłu obronnego; promowanie badań i technologii w dziedzinie obrony w UE z uwzględnieniem priorytetów politycznych UE; działanie - w ścisłej współpracy z Komisją - na rzecz rozwoju konkurencyjnego w skali światowej europejskiego rynku uzbrojenia.

W końcowej fazie prac Konwentu Europejskiego w czasie posiedzenia Rady Europejskiej w Salonikach (19-20 czerwca 2003 r.) zaprezentowano projekt strategii bezpieczeństwa Unii pt. „Bezpieczna Europa w lepszym świecie”, przygotowany przez Wysokiego Przedstawiciela UE do spraw WPZiB J. Solanę. Prace nad strategią podjęto w ścisłym porozumieniu pomiędzy państwami członkowskimi i Komisją Europejską. W dokumencie tym omówione zostały wszystkie ryzyka i zagrożenia dla europejskiego bezpieczeństwa i stabilności oraz zaproponowany został katalog środków koniecznych dla zapobiegania kryzysom. Dokument wymieniał trzy główne sytuacje kryzysogenne wywołane: terroryzmem, zastosowaniem broni masowego rażenia i niebezpieczeństwami płynącymi z tzw. państw niestabilnych. Strategia zakłada, że europejska polityka zagraniczna może być tylko wtedy skuteczna w sytuacjach kryzysowych, jeśli UE będzie w stanie w razie potrzeby przeforsować swoje żądania, w przypadku ekstremalnym i ostatecznym także poprzez zastosowanie siły wojskowej. Chodzi tu o kwestię ew. wyjścia poza dotychczasowe ramy Misji Petersberskich (,,pre-emptive actions"). Zakłada się tu więc, że Europa musi dalej rozbudowywać swoje zdolności wojskowe. Ważne jest również, że w zakresie Europejskiej Polityki Bezpieczeństwa i Obrony może być wykorzystany instrument wzmocnionej współpracy, a awangarda państw członkowskich ma możliwość posuwania do przodu integracji także w tym zakresie: jako otwarty proces, w którym mogą uczestniczyć wszyscy obecni i przyszli członkowie UE. Nie skierowany przeciwko NATO, lecz wzmacniający europejski filar partnerstwa transatlantyckiego ${ }^{29}$.

Opracowywana doktryna wskazuje na przydatność łagodnej siły, jaką w tym przypadku dysponuje UE, a która obejmuje: pomoc zagraniczną i rozciagnięcie strefy bezpieczeństwa wokół Europy, wspieranie demokracji i budowę instytucji państwowych, a zwłaszcza umocnie-

${ }^{28}$ Posiedzenie Rady Europejskiej w Brukseli, 20-21 marca 2003 r., Wnioski Prezydencji, ,Monitor Integracji Europejskiej" 2003, nr 63, s. 67-68.

${ }^{29}$ Biuletyn Unia Europejska, opr. J. Mękosa, lipiec 2003, Ministerstwo Spraw Zagranicznych, Departament Systemu Informacji. Tekst pobrano ze strony internetowej: www.msz.gov.pl. 
nie ,skutecznego multilateralizmu”, którego ,podstawowe ramy” stanowiłaby Karta Narodów Zjednoczonych ${ }^{30}$. Nie bez znaczenia dla tej doktryny byłaby konstrukcja bezpieczeństwa międzynarodowego lansowanego w Unii Europejskiej oparta na „kwartecie” (złożonym z USA, UE, ONZ oraz Federacji Rosyjskiej).

W trakcie posiedzenia Rady Europejskiej w Salonikach postanowiono również o: - ustanowieniu grup projektowych w ramach realizacji ECAP; - dalszych pracach w zakresie zarządzania kryzysami wewnętrznymi; - wdrożeniu uzgodnień (ze szczególnym uwzględnieniem inicjatywy „Berlin plus”) dotyczących organizacji strategicznego partnerstwa między UE i NATO; - realizacji programu zapobiegania gwałtownym konfliktom ${ }^{31}$. Strategia bezpieczeństwa UE przyjęta została w trakcie posiedzenia Rady Europejskiej w Brukseli 12 grudnia 2003 r., którą należy analizować wspólnie z przyjętą tam również deklaracją w sprawie stosunków transatlantyckich, w której to wyeksponowano znane już argumenty: - wezwanie do kształtowania nowego porządku międzynarodowego opartego na multilateralizmie $^{32}$, szczególnie ważnego w relacjach do polityki amerykańskiego interwencjonizmu; - wspólnej (transatlantyckiej) współpracy państw na rzecz celów zapisanych w ESS; - konieczność podejmowania równoczesnych akcji prewencyjnych o charakterze wojskowym, policyjnym i cywilnym; - dalszej współpracy w ramach formuły porozumień „Berlin-plus"33.

\section{Podstawowe problemy warunkujące dalszy rozwój Europejskiej Strategii Bezpieczeństwa ${ }^{34}$}

Pięć lat po przyjęciu Europejskiej Strategii Bezpieczeństwa przed Unią Europejską stoją większe obowiązki niż kiedykolwiek w jej dotychczasowej historii. Rozszerzenie Unii w 2004 i 2007 r. rozprzestrzeniło demokrację i stabilność na całym kontynencie. Polityka sąsiedztwa stworzyła silne ramy, w których rozwijają się aktywne stosunki z partnerami na Południu i na Wschodzie, czemu nowy wyraz dają obecnie Unia dla Śródziemnomorza i Partnerstwo Wschodnie. Od roku 2003 UE coraz częściej skutecznie przyczynia się do rozwiązywania sytuacji kryzysowych i konfliktowych, np. w Afganistanie i Gruzji. A jednak, dwadzieścia lat od zakończenia zimnej wojny Europa stoi przed coraz bardziej złożonymi zagrożeniami i wyzwaniami. Konflikty na Bliskim Wschodzie i w innych częściach świata pozostają nierozwiązane, inne wybuchają, także w sąsiedztwie Europy.

Globalizacja przyniosła nowe szanse. Dynamiczny wzrost gospodarczy w krajach rozwijających się, wśród których wiodą Chiny, wyzwolił miliony ludzi z ubóstwa. Ale globalizacja spowodowała również, że zagrożenia są bardziej złożone i wzajemnie ze sobą powiązane. Główne arterie społeczeństw - takie jak systemy informatyczne i dostawy energii - są bar-

\footnotetext{
${ }^{30}$ J. Solana, Droga Europy do bezpieczeństwa, „Rzeczpospolita”, 12 grudnia 2003.

${ }^{31}$ Posiedzenie Rady Europejskiej w Salonikach, 19-20 czerwca 2003 r., Wnioski Prezydencji, ,Monitor Integracji Europejskiej" 2003, nr 64, s. 91-92.

${ }^{32}$ Cytat z deklarcji: „The EU calls for an international order based on effective multilateralism”.

${ }^{33}$ O współpracy operacyjnej Unii Europejskiej i NATO, której podstawą była wymiana listów z 17 marca 2003 r. pomiędzy Sekretarzem Generalnym NATO a Wysokim Przedstawicielem do spraw WPZiB/Sekretarzem Generalnym Rady UE.

${ }^{34}$ Przygotowano na podstawie: Sprawozdanie na temat wdrażania europejskiej strategii bezpieczeństwa-utrzymanie bezpieczeństwa w zmieniajacym sięświecie, Dokument Wysokiego Przedstawiciela do spraw Wspólnej Polityki Zagranicznej i Bezpieczeństwa Unii Europejskiej nr S407/08, Bruksela, 11 grudnia 2008 r.
} 
dziej narażone na uszkodzenia. Globalne ocieplenie i pogarszający się stan środowiska zmieniają oblicze planety. Ponadto globalizacja przyspiesza przemieszczanie się centrów władzy i odsłania zróżnicowanie systemów wartości. Ostatnie wstrząsy finansowe zachwiały zarówno rozwiniętymi, jak i rozwijającymi się gospodarkami.

$\mathrm{Na}$ szczeblu globalnym Europa musi przewodzić odnowie ładu multilateralnego. Na szczycie systemu międzynarodowego stoi ONZ. Cokolwiek UE uczyniła w dziedzinie bezpieczeństwa, było powiązane z celami ONZ. Jest to wyjątkowy moment, aby odnowić multilateralizm we współpracy ze Stanami Zjednoczonymi oraz partnerami na całym świecie. Dla Europy partnerstwo transatlantyckie pozostaje niezastapionym fundamentem, opartym na wspólnej historii i odpowiedzialności. Unia Europejska i NATO muszą pogłębić swoje partnerstwo strategiczne, aby lepiej współpracować w dziedzinie zarządzania kryzysowego.

W Europejskiej Strategii Bezpieczeństwa określono szereg zagrożeń i wyzwań dla naszych interesów bezpieczeństwa. Po prawie sześciu latach żadne z nich nie znikły; niektóre stały się znaczniejsze, a wszystkie jeszcze bardziej złożone. Pierwszym problemem jest nadal rozprzestrzenianie broni masowego rażenia. Proliferacja, zarówno z udziałem państw, jak i terrorystów, została w Strategii uznana za potencjalne największe zagrożenie bezpieczeństwa $U E$. Ryzyko to wzrosło w ciagu ostatnich lat, co wywarło presję na struktury multilateralne. Wprawdzie Libia wycofała się z programu BMR, ale Iran i Korea Północna muszą sobie jeszcze zasłużyć na zaufanie społeczności międzynarodowej. Ponowny wzrost zainteresowania cywilnym wykorzystaniem energii jądrowej, który prawdopodobnie nastapi w nadchodzących dziesięcioleciach, stworzy również wyzwania dla systemu nieproliferacji, o ile nie będą mu towarzyszyły odpowiednie środki zabezpieczające. UE działała również bardzo aktywnie na forach międzynarodowych na podstawie strategii BMR przyjętej w roku 2003. Była także obecna w pierwszej linii w międzynarodowych działaniach związanych z irańskim programem jądrowym. Strategia kładzie nacisk na zapobieganie - realizowane za pomocą działań w ramach ONZ i układów multilateralnych, jako znaczący darczyńca i we współpracy z państwami trzecimi i organizacjami regionalnymi w celu wzmocnienia ich zdolności zapobiegania proliferacji. Dalsze prace potrzebne są również w kwestiach szczegółowych, w tym: wsparcia UE dla multilateralnego podejścia do cyklu życia paliw jądrowych; przeciwdziałania finansowaniu proliferacji; środków bezpieczeństwa biologicznego i ochrony biologicznej; ograniczenie rozprzestrzeniania systemów przenoszenia broni, w szczególności pocisków balistycznych. Należy też rozpocząć negocjacje międzynarodowego traktatu zabraniającego produkcji materiałów rozszczepialnych dla broni jądrowej.

Kolejnym ważnym problemem w ramach ESB jest terroryzm i przestępczość zorganizowana. Od roku 2003 UE osiągnęła postępy w zwalczaniu obu problemów, wykorzystując dodatkowe środki wewnątrz Unii w ramach programu haskiego z roku 2004 i nową strategię dotyczącą zewnętrznego wymiaru WSiSW ${ }^{35}$ przyjętą w roku 2005. Środki te ułatwiły prowadzenie transgranicznych dochodzeń i koordynację stawiania przed sądem.

Strategia antyterrorystyczna UE, również pochodząca z roku 2005, opiera się na poszanowaniu praw człowieka i prawa międzynarodowego. Jej podejście jest czterotorowe: zapobieganie radykalizacji i rekrutacji oraz czynnikom leżącym u ich podstaw; ochrona potencjalnych celów; ściganie terrorystów oraz reagowanie na skutki ataku. Choć największe znaczenie mają działania na szczeblu krajowym, mianowanie koordynatora ds. zwalczania terroryzmu było istotnym krokiem na szczeblu europejskim.

\footnotetext{
${ }^{35}$ Wymiar Sprawiedliwości i Sprawy Wewnętrzne Unii Europejskiej.
} 
W zakresie przestępczości zorganizowanej należy pogłębić istniejące partnerstwa w sąsiedztwie UE i z głównymi partnerami oraz w ramach ONZ, przez zwrócenie uwagi na przemieszczanie się osób oraz współpracę policyjną i sądową. Fundamentalne znaczenie ma wprowadzanie w życie istniejących instrumentów ONZ w dziedzinie przestępczości. Unia Europejska jest zobowiązana jeszcze bardziej zacieśnić partnerstwo antyterrorystyczne ze Stanami Zjednoczonymi, w tym również w dziedzinie wymiany i ochrony danych. Należy wzmocnić zdolności partnerów w Azji Wschodniej, Afryce i wśród południowych sąsiadów.

Kolejny problem to cyberbezpieczeństwo. Nowoczesne gospodarki w dużym stopniu zależą od krytycznej infrastruktury, w tym transportu, łączności i dostaw energii, ale też - od Internetu. Przyjęta w roku 2006 strategia UE na rzecz bezpiecznego społeczeństwa informacyjnego w Europie zwraca uwagę na problem przestępczości internetowej. Jednakże ataki skierowane na prywatne lub rządowe systemy informatyczne w państwach członkowskich UE nadały mu nowy wymiar, jako potencjalnej nowej broni ekonomicznej, politycznej i wojskowej. W obszarze tym konieczne są dalsze prace w celu przeanalizowania możliwości przyjęcia kompleksowego podejścia unijnego, podniesienia poziomu świadomości i zacieśnienia współpracy międzynarodowej.

Następny problem to bezpieczeństwo energetyczne. Obawy dotyczące uzależnienia od dostaw energii zwiększyły się w ciągu ostatnich pięciu lat. Spadająca produkcja w obrębie Europy oznacza, że do roku 2030 do $75 \%$ naszej ropy i gazu trzeba będzie importować. Dostawy będą pochodzić z ograniczonej liczby krajów, z których wiele stoi w obliczu zagrożeń dla swojej stabilności. UE stoi zatem w obliczu szerokiej gamy wyzwań dla bezpieczeństwa, które wymagają odpowiedzialności i solidarności od wszystkich państw członkowskich. Reakcję Europy musi stanowić polityka energetyczna UE, która łączy w sobie aspekt zewnętrzny i wewnętrzny. Jej główne elementy przedstawiono we wspólnym sprawozdaniu Wysokiego Przedstawiciela i Komisji z czerwca 2006 roku. Wewnątrz Europy potrzebny jest bardziej zunifikowany rynek energii o większej łączności wewnętrznej. Trzeba także poświęcić szczególną uwagę krajom najbardziej odizolowanym oraz opracować metody radzenia sobie z kryzysem w przypadku tymczasowych przerw w dostawach. Niezbędna jest też większa dywersyfikacja paliw, źródeł dostaw oraz tras przesyłu, jak również dobre rządy, poszanowanie praworządności i inwestycje w państwach pochodzenia. Polityka UE wspiera te założenia przez zaangażowanie w Azji Środkowej, na Kaukazie i w Afryce, a także za pośrednictwem Partnerstwa Wschodniego i Unii dla Śródziemnomorza. Energia stanowi ważny czynnik w stosunkach UE z Rosją. Polityka UE powinna obejmować trasy przesyłu, również przez Turcję i Ukrainę. Wraz z partnerami, w tym z Chinami, Indiami, Japonią i USA Unia powinna promować energię ze źródeł odnawialnych, technologie niskoemisyjne i efektywność energetyczną, wraz z przejrzystymi i dobrze regulowanymi rynkami światowymi.

Na liście wyzwań dla Europejskiej Strategii Bezpieczeństwa nie może zabraknąć też problemu zmian klimatycznych. W 2003 roku w ESB określono implikacje zmian klimatycznych dla bezpieczeństwa. Pięć lat później kwestia ta stała się bardziej pilna. W marcu 2008 roku Wysoki Przedstawiciel i Komisja przedstawili na forum Rady Europejskiej sprawozdanie, w którym zmiany klimatyczne określono jako czynnik zwielokrotniajacy zagrożenia. Klęski żywiołowe, degradacja środowiska i konkurowanie o zasoby zaostrzają konflikty, zwłaszcza w sytuacjach ubóstwa i wzrostu liczby ludności, co rodzi skutki w zakresie humanitarnym, zdrowotnym, politycznym i bezpieczeństwa, w tym większą migrację. Zmiany klimatyczne mogą także prowadzić do sporów o trasy handlowe, strefy morskie i uprzednio niedostępne zasoby. 


\section{Pozatraktatowa aktywność Unii Europejskiej w ramach Europejskiej Strategii Bezpieczeństwa ${ }^{36}$. Dalsze rozszerzanie wpływów Unii Europejskiej}

W przypadku Turcji negocjacje rozpoczęły się w roku 2005 i od tego czasu otwarto liczne rozdziały. Postęp na Bałkanach Zachodnich jest stały, choć powolny. Negocjacje z Chorwacją w sprawie przystąpienia są na zaawansowanym etapie. Była Jugosłowiańska Republika Macedonii uzyskała status kandydata. Umowy o stabilizacji i stowarzyszeniu podpisano z pozostałymi państwami Bałkanów Zachodnich. Serbia jest bliska spełnienia wszystkich warunków na drodze do pogłębienia stosunków z UE. UE nadal odgrywa wiodącą rolę w Bośni i Hercegowinie. W Kosowie rozmieszczono misję EULEX - największą misję cywilną w ramach Europejskiej Polityki Bezpieczeństwa i Obrony.

Rozpoczęta w 2004 roku Europejska Polityka Sąsiedztwa (EPS) wspiera proces rozwoju państw graniczących z UE. Na wschodzie uczestniczą w niej wszystkie kwalifikujące się kraje z wyjątkiem Białorusi. W przypadku Ukrainy UE posunęła się dalej i opracowała daleko idący układ o stowarzyszeniu, który jest bliski sfinalizowania. Niedługo rozpoczną się negocjacje z Republiką Mołdowy na temat podobnej umowy. Synergię czarnomorską uruchomiono z zamiarem uzupełnienia polityk dwustronnych UE prowadzonych w tym szczególnie ważnym dla Europy regionie.

W basenie Morza Śródziemnego obserwowane są nadal niedostateczne reformy polityczne i nielegalna migracja. UE i kilku partnerów śródziemnomorskich, zwłaszcza Izrael i Maroko, pracują nad pogłębieniem stosunków dwustronnych. EPS utrwaliła reformy pierwotnie rozpoczęte w ramach procesu barcelońskiego w roku 1995, ale konflikty regionalne w połączeniu z rosnącym radykalizmem nadal powodują niestabilność.

UE odgrywała wiodącą rolę w staraniach na rzecz osiągnięcia zgody na Bliskim Wschodzie przez swój udział w kwartecie, współpracę z Izraelem i Autonomią Palestyńską, Ligą Arabską i z innymi partnerami regionalnymi. W Libanie państwa członkowskie wspierają w istotny sposób misję pokojową UNIFIL. W przypadku Iraku UE wspierała proces polityczny, odbudowę i praworządność, także za pośrednictwem misji EUJUST LEX. Od roku 2003 Iran stanowi coraz poważniejszy powód do obaw. Irański program jądrowy był przedmiotem kolejnych rezolucji RB ONZ i MAEA. Rozwinięcie jądrowej zdolności militarnej stanowiłoby niedopuszczalne zagrożenie dla bezpieczeństwa UE. Unia, przy udziale USA, Chin i Rosji prowadziła dwutorowe podejście łączące dialog z rosnącym naciskiem. Wysoki Przedstawiciel ds. WPZiB przekazał Iranowi szeroko zakrojoną ofertę odbudowy zaufania do społeczności międzynarodowej i udziału w niej. Jeżeli zamiast tego program jądrowy będzie kontynuowany, rosła będzie potrzeba opracowania dodatkowych środków wspierających proces ONZ. Jednocześnie potrzebujemy współpracować z państwami regionu, w tym z krajami Zatoki Perskiej, w celu tworzenia bezpieczeństwa w regionie.

W ESB stwierdzono, że Europa posiada interesy w zakresie bezpieczeństwa poza jej bezpośrednim sąsiedztwem. W tym zakresie Afganistan jest szczególnym powodem do niepokoju. Europa ma długoterminowe zobowiązanie na rzecz przywrócenia temu krajowi stabilności. Państwa członkowskie UE mają znaczący udział w misji NATO, a UE jest zaangażowana na

\footnotetext{
${ }^{36}$ Przygotowano na podstawie: Sprawozdanie na temat wdrażania europejskiej strategii bezpieczeństwa - utrzymanie bezpieczeństwa w zmieniajacym się świecie, Dokument Wysokiego Przedstawiciela do spraw Wspólnej Polityki Zagranicznej i Bezpieczeństwa Unii Europejskiej nr S407/08, Bruksela, 11 grudnia 2008 r.
} 
wszystkich szczeblach na rzecz dobrych rządów i rozwoju. Rozszerzana jest także misja policyjna $\mathrm{UE}^{37}$.

UE coraz ściślej współpracuje z organizacjami regionalnymi, a w szczególności z Unią Afrykańską. Poprzez wspólną strategię Afryka-UE wspierane jest zwiększenie afrykańskich zdolności w zakresie zarządzania kryzysowego, w tym regionalne siły gotowości i wczesne reagowanie. Zacieśnione zostały stosunki z partnerami z Azji Środkowej w ramach strategii przyjętej w 2007 roku, przez wzmocnienie dialogu politycznego oraz działania na rzecz takich kwestii jak: woda, energia, praworządność i bezpieczeństwo. W innych obszarach UE rozwinęła powiązania z ASEAN wokół kwestii regionalnych, takich jak Birma, z SAARC i Ameryką Łacińską. Dzięki swemu doświadczeniu UE odgrywa szczególną rolą w sprzyjaniu integracji regionalnej.

W pięcioletnim okresie prowadzenia Europejskiej Strategii Bezpieczeństwa przeprowadzono z powodzeniem pierwsze operacje wojskowe UE. W Macedonii pod dowództwem UE (przejęcie odpowiedzialności od NATO) została przeprowadzona Operacja Concordia (marzec-grudzień 2003 r.), wnosząca istotny wkład w odzyskanie niepodległości przez Macedonię. Pierwszą operacją przeprowadzoną przez UE samodzielnie była misja Artemida (czerwiec-wrzesień 2003 r.), czyli działania stabilizacyjne po rozruchach w prowincji Bunia w Kongo. Po ich skutecznej realizacji odpowiedzialność przeszła w ręce misji ONZ MONUC. W roku 1999 UE przejęła kierownictwo misji Althea w Bośni-Hercegowinie luzując w ten sposób natowską misję SFOR. Jesienią 2006 r. w ramach EUFOR RD CONGO UE zabezpieczała pierwsze od 40 lat wolne wybory w Kongo. Do tego doszły jeszcze operacje cywilne, np. policyjna „Operacja Proxima” w Macedonii, czy misja policyjna UE EUPOL w Kinszasie, wspierająca odbudowę policji w Kongo ${ }^{38}$.

Już dawno rozpoczęła się integracja europejskich sił zbrojnych. W ubiegłych latach mieliśmy szereg dobrych przykładów bliskiej współpracy partnerów unijnych, po części także w ramach NATO:

— brygada niemiecko-francuska powołana do życia w 1989 r.;

- Eurokorpus w Sztrasburgu (Niemcy, Francja, Belgia, Hiszpania, Luksemburg);

- European Airlift Centre w Eindhoven powstałe z założonego w roku 2001 European Air Coordination Cell;

- korpus niemiecko-holenderski z siedzibą w Monastyrze (1995 r.);

- Saelift Coordination Centre (2003 r.): dziewięć państw zapewnia sobie nawzajem dostęp do trzech statków transportowych;

— Wielonarodowy Korpus Północ-Wschód w Szczecinie (Niemcy, Dania, Polska);

— wspólna jednostka obrony przed minami państw basenu Morza Bałtyckiego (Baltic Naval Squadron) ze wspólną kwaterą główną batalionu na Łotwie;

— wspólna kwatera główna marynarki wojennej państw Beneluksu w Den Helder;

- holenderski przykład w transporcie powietrznym: zamiast zakupu własnych samolotów transportowych (niosącym za sobą koszty związane z infrastruktura, przeglądami, personelem, itp.) Holandia podpisała porozumienie z Niemcami dotyczące wykorzystania odpowiednich niemieckich zasobów transportowych;

\footnotetext{
${ }^{37}$ Sprawozdanie na temat wdrażania europejskiej strategii bezpieczeństwa-utrzymanie bezpieczeństwa w zmieniajacym się świecie, Dokument Wysokiego Przedstawiciela do spraw Wspólnej Polityki Zagranicznej i Bezpieczeństwa Unii Europejskiej nr S407/08, Bruksela, 11 grudnia 2008 r.

${ }^{38}$ Na drodze ku europejskiej armii. Artykuł posła Bundestagu Steffena Reiche o armii europejskiej. Stanowisko grupy roboczej: Zagadnienia bezpieczeństwa oraz sprawy Unii Europejskiej. Stan: 27 marca 2007 r.
} 
— ochrona przestrzeni powietrznej państw bałtyckich: W związku z tym, że państwa bałtyckie nie dysponują odpowiednimi statkami powietrznymi, kraje NATO utrzymując $w$ jednej z litewskich baz odpowiednie samoloty wojskowe wraz z niezbędnym personelem naziemnym, pełnią rolę Air Policing;

- wspólna, pewna i szybka możliwość skorzystania ze strategicznych środków transportu powietrznego dla przemieszczania sił szybkiego reagowania NATO i UE: piętnaście państw, w tym Niemcy, podpisało wspólną umowę z firmą Ruslan SALIS Sp. z o.o. stawiającą do dyspozycji NATO i UE w przypadku przeprowadzania przez nie wielonarodowych operacji do sześciu statków powietrznych Antonow 124-100;

- flota AWACS - chociaż jest to projekt NATO, stanowi dobry przykład wspólnego działania;

- wielonarodowe dowództwa sił zbrojnych EUROFOR (European Operational Rapid Force) i EUROMARFOR (European Maritime Force), w których uczestniczą: Francja, Hiszpania, Włochy, Portugalia ${ }^{39}$.

\section{Zamiast zakończenia: Przyszłość europejskiej polityki zagranicznej w zakresie bezpieczeństwa}

Współczesna definicja bezpieczeństwa powinna mieścić w sobie szerokie spektrum zagadnień: od bezpieczeństwa państwa w tradycyjnym sensie do bezpieczeństwa człowieka w różnych aspektach jego bytowania. Myśląc o bezpieczeństwie, musimy mieć zatem na uwadze politykę obronną, siły zbrojne, kwestie ekonomiczne i społeczne, stabilność polityczną, bezpieczeństwo demokracji, której legitymizm może być zagrożony przez korupcję czy ubóstwo szerszych grup społecznych, ochronę środowiska naturalnego, zagrożenia pochodzące z katastrof technologicznych w rodzaju czarnobylskiej awarii, masowe naruszenia praw człowieka, w tym praw mniejszości narodowych, napięcia etniczne wewnątrz poszczególnych państw i na ich granicach, żywiołowe migracje na dużą skalę czy wspomnianą wcześniej przestępczość zorganizowaną. Ta lista może być z pewnością dłuższa. Nie chodzi tu jednak o to, by wskazać je wszystkie, lecz by mieć świadomość rozpiętości tych zagrożeń, a co za tym idzie świadomość konieczności kreatywnego, niekonwencjonalnego myślenia i działania w tej sferze ${ }^{40}$.

W podsumowaniu warto podkreślić główne czynniki, które określą przyszłą europejską politykę bezpieczeństwa. Oto one:

— wola polityczna, aby działać razem i realizować wspólne interesy UE;

— poczucie solidarności i poszanowanie innych partnerów i ich wrażliwości;

- ustanowienie mechanizmów rozwiązywania wewnętrznych kryzysów w UE - w przeciwnym razie zachwianiu ulegnie pozycja UE i jej państw członkowskich;

— tożsamości europejskiej nie można budować na sentymentach anty-amerykańskich; Stany Zjednoczone powinny pozostać najważniejszym partnerem dla UE;

- państwa wstępujące do UE są gotowe przystąpić do współpracy w ramach WPZiB oraz EPBiO, wnieść swój wkład w tę współpracę i rozwinąć własne zdolności. Należy

\footnotetext{
${ }^{39}$ Ibidem, s. 8 .

${ }^{40}$ W. Bartoszewski, Europejska polityka bezpieczeństwa. Polski punkt widzenia, przemówienie wygłoszone na konferencji zorganizowanej przez Uniwersytet Warszawski i Ministerstwo Spraw Zagranicznych, Warszawa, 11 maja 2001 roku, tekst pobrano ze strony internetowej: http:/www.futurum.gov.pl/futurum.nsf /11/12/2008/.
} 
wykorzystać ten potencjał dla dobra WPZiB i to nie tylko w zakresie Wschodniej Polityki $\mathrm{UE}^{41}$;

- w czasach globalizacji Unia o takich rozmiarach, potencjale i interesach posiada obowiązek ponoszenia swojej części odpowiedzialności. Teoretycznie UE mogłaby nie podjąć takiego wyzwania, jednakże i tak nie byłaby w stanie uniknąć konsekwencji takiej postawy.

Jeżeli chodzi o polski wkład w rozwój Europejskiej Strategii Bezpieczeństwa należy wziąć pod uwagę następujące rekomendacje:

— z powodów geopolitycznych Polska winna dążyć do jak największej spoistości politycznej i militarnej Unii Europejskiej. W naszym interesie leży też zmiana wizerunku Polski jako państwa utrudniającego dalszą integrację Unii. Rząd polski powinien wyrazić jednoznaczną, nieograniczoną zastrzeżeniami, gotowość uczestniczenia w działaniach zmierzających do ożywienia Wspólnej Polityki Zagranicznej i Bezpieczeństwa UE oraz Europejskiej Polityki Bezpieczeństwa i Obrony ${ }^{42}$;

- Polska powinna włączać się do wszelkich inicjatyw, które zechcą rozwijać pogtębiona strukturalnq wspótpracę w zakresie Wspólnej Polityki Zagranicznej i Bezpieczeństwa oraz Europejskiej Polityki Bezpieczeństwa i Obrony;

- ambicją Polski jest umocnienie i precyzowanie zewnętrznej roli Unii. Dotyczy to w szczególności wymiaru wschodniego. Chcemy stać się pomostem między Unią a jej przyszłymi wschodnimi sąsiadami, z którymi gotowi jesteśmy dzielić się naszym doświadczeniem i know-how okresu transformacji, czyniąc politykę wschodnią Unii bardziej otwartą i konstruktywną. Nasze doświadczenie, stopień rozwoju i stabilna infrastruktura współpracy gospodarczej i administracyjnej ze wschodnimi sąsiadami mogą przyczynić się do rozwoju polityki wschodniej Unii Europejskiej.

\section{Summary}

In 2003, the Council of Europe, the highest political organ of the European Union, resolved to adopt the European Security Strategy. This document outlined three fundamental objectives for the EU: stability and good governance in the area of the EU's closest neighbors; creating an international order that would be based not only on bilateral relations, but primarily on efficient multilateral relations; and preventing threats, whether new or traditional. The Strategy assumed that the EU would take the responsibility for international security both in the realm of 'peace keeping' (peace and defensive missions) and 'peace-making' (peace and offensive missions).

Defining the threats that the European Union needs to defy, the Strategy enumerates local conflicts, terrorism, the proliferation of weapons of mass destruction and their potential use against the territory of the EU and its member states, collapsing states, and conflicts breaking out in such states and their neighborhood, as well as organized crime.

\footnotetext{
${ }^{41}$ W. Cimoszewicz, wykład ministra spraw zagranicznych pt. Przyszłość wspólnej polityki zagranicznej i bezpieczeństwa wygłoszony w fundacji Friedricha Eberta w Berlinie,12.03.2003, tekst pobrano ze strony internetowej: http://www.futurum.gov.pl/futurum.nsf /11/12/2008/.

${ }^{42}$ Z. Najder, Polska wobec Wspólnej Polityki Zagranicznej i Bezpieczeństwa. Propozycja nowego stanowiska, „Analizy i opinie Instytutu Spraw Publicznych” 4/2003, tekst pobrano ze strony internetowej: http://www.futurum.gov.pl/futurum.nsf /14/12/2008/.
} 
The assessment of numerous threats to internal and external security, presented in the European Security Strategy, remains up-to-date. There have also emerged new threats for Europe that result from the need to ensure energy security, primarily with respect to the diversification of energy sources. The significance of climate change to international security has increased. The same applies to IT security or piracy. The EU has been rather anxious about the intensification of frozen conflicts, in particular the outbreak of war between Russia and Georgia.

The Polish Ministry of Foreign Affairs has indicated that the enlargement process is a significant stabilizing factor in the EU neighborhood. Fundamental importance is also attached to the review of cooperation principles with the USA, the crucial role of the UN in the international system, and cooperation with regional organizations, such as the African Union. There is also the need to develop a strategic partnership with NATO, in particular in terms of operational cooperation. Another key factor in the strengthening of the EU's global position is the development of a civil and military crisis response system. 
